Pamiętnik Literacki 2018, 1, s. 199-216
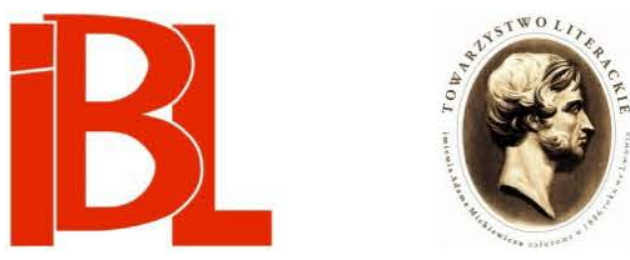

\title{
Józef Wittlin - na szlakach ucieczki i ocalenia
}

Ryszard Zajączkowski 
Pamiętnik Literacki CIX, 2018, z. 1, PL ISSN 0031-0514

DOI:10.18318/pl.2018.1.11

RYSZARD ZAJĄCZKOWSKI Katolicki Uniwersytet Lubelski Jana Pawła II

JÓZEF WITTLIN - NA SZLAKACH UCIECZKI I OCALENIA

Ukazujące się od lat dziewięćdziesiątych XX w. prace dotyczące Józefa Wittlina koncentrują się głównie na ponownym odczytaniu jego wierszy, esejów i powieści Sól ziemi, zwłaszcza że przez długi czas twórczość ta nie była publikowana ani omawiana. Znacznie mniejsza jest wiedza na temat faktów $\mathrm{z}$ życia pisarza, jego korespondencji, jak też szeregu tekstów pozostających do dziś w różnych archiwach. Tymczasem zapełnienie luk w tej dziedzinie wzbogaca w znakomitym stopniu obraz jego twórczości, daje jej pogłębione rozumienie, a także pozwala lepiej wczuć się w sytuacje polskich twórców na emigracji.

\section{Po drogach wojennej Europy}

Z korespondencji Józefa Wittlina $z$ Hermanem Kestenem ${ }^{1}$ wynika, że na początku maja 1939 ten pierwszy zaczął przygotowywać się do kolejnej swojej wizyty w Abbaye de Royaumont ${ }^{2}$, by 9 VII 1939 razem z Tymonem Terleckim wyjechać z Warszawy ${ }^{3}$. Pobyt pisarza w tym miejscu, planowany na dłużej, trwał tylko około dwóch miesięcy - zakłóciła go trudna sytuacja polityczna, złe samopoczucie, a przede wszystkim wojna, która oznaczała brutalny i definitywny koniec beztroskiego pobytu w byłym opactwie. Kilkadziesiąt lat później Terlecki tak wspominał ów wyjazd:

Niemcy już zbrojące się do napadu na Polskę przejechaliśmy razem z Wittlinem i w tej podróży, która właściwie rozstrzygnęła o losie jego i moim, zapamiętałem to zbiorowisko samolotów bojowych na Tempelhof, bo pociąg mijał lotnisko i samoloty stały gęsto ustawione jeden przy drugim. Wittlin, jak

1 Hermann Kesten (1900-1996) - niemiecki pisarz i wydawca. Wittlin poznał go pod koniec lat dwudziestych XX stulecia w Berlinie, gdzie Kesten pracował w Wydawnictwie Kiepenheuer, w którym Wittlin chciał opublikować Sól ziemi. Ponownie spotkał się z Kestenem w Paryżu w celu skonsultowania francuskiego tłumaczenia swej powieści, która miała się ukazać w holenderskiej oficynie Allert de Lange. Zob. R. Zają c zk ow ski, Literatura i życie. O wspótpracy Józefa Wittlina z Walterem Landauerem i tłumaczeniach „Soli ziemi”. „Pamiętnik Literacki” 2016, z. 1.

2 Pierwszy wyjazd pisarza do Foyer d'Abbaye de Royaumont. Lieu de travail ou de repos destine aux artistes et intellectueles - jak brzmiała pełna nazwa tego miejsca - nastapił jesienią 1938. Owocem tego pobytu był esej J. Wittli in a Abbaye de Royaumont („Wiadomości Literackie” 1939, nr 27). 30 V 1939 J. Wittlin pisał do H. Kestena: „Od miesiąca czynię przygotowania do podróży, są jednak trudności (paszport), które jeszcze nie zostały przezwyciężone”. Z kolei w liście do niego z 21 VIII 1939 donosił: „Jestem już szósty tydzień w Royaumont - ale nie czuję się dobrze - z powodu sytuacji politycznej mam bóle jelit”. Korespondencja odbywała się w jezzyku niemieckim; cytaty sa podane w moim tłumaczeniu. Wszystkie przywołane tu listy Wittlina do Kestena znajdują się w: Bibl. Monacensia w Monachium. Archiwum Hermanna Kestena. Korespondencja H. Kestena $\mathrm{z}$ J. Wittlinem. 
zobaczył ten obraz, zbladł jak ściana. Przeczuł, że wojna jest nieuchronna, że wojna się zbliża i że my obydwaj unosimy, świadomie czy nieświadomie, nasze głowy z grożącej naszemu krajowi katastrofy ${ }^{4}$.

Wittlin niecodzienną sytuację zastaną w podparyskim opactwie komentował krótkimi notatkami w pozostawionej w brudnopisie powieści Raptus Europae. W odniesieniu do swego położenia w Royaumont napisał:

Byłem ostatnim gościem w Foyer - zostałem sam jeden z moimi lękami o was [tj. o żonę i córkę R. Z.], z rozpaczą wśród tylu wspaniałych ruin - sam ruina, choć nie bardzo wspaniała. Wymiatają mnie $\operatorname{stamtąd}^{5}$.

Okres od wyjazdu z Abbaye de Royaumont do zaokrętowania się na statek płynący do Ameryki Wittlin zamierzał przedstawić właśnie we wspomnianym utworze. Był on projektowany zwłaszcza $z$ myślą o córce, $z$ chęci pozostawienia dla niej zapisu tej wyjątkowej historii. Miał utrwalić traumatyczne doświadczenia ludzi wyzutych nie tylko z rodzinnego domu, lecz także z Europy jako przestrzeni duchowej. Raptus Europae nie uzyskał jednak nigdy skończonej postaci; nie wyszedł poza etap nieco uporządkowanego zbioru notatek. Szkic tekstu, który się zachował, Wittlin opracowywał wkrótce po przyjeździe do Ameryki ${ }^{6} \mathrm{w}$ oparciu o zapiski gromadzone od r. 1936, kiedy od kwietnia do lipca przebywał we Francji, poszukując francuskiego tłumacza Soli ziemi oraz pracując nad jej kolejnymi tomami. Rękopis Raptus Europae, choć nie jest pozbawiony walorów literackich, ma jednak przede wszystkim wartość dokumentacyjną, zwłaszcza w odniesieniu do lat 1936-1941. Z notatek pisarza wiadomo, że 1 IX 1939 wrócił on do Paryża ${ }^{7}$ i tam podjął energiczne działania w celu sprowadzenia rodziny (co udało mu się dopiero „około

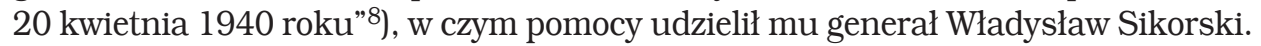

J. Wittlin, Raptus Europae. Muzeum Literatury im. A. Mickiewicza w Warszawie, rkps 1697, k. 41.

Informacja o pracy Wittlina nad tym utworem pojawiła się w memoriale „Koła Pisarzy z Polski”, wydanym prawdopodobnie w połowie maja 1942, adresowanym „Do Pana Ministra Informacji i Dokumentacji Stanisława Strońskiego w Londynie”. Zob. B. D o r o s z, Nowojorski pasjans. Polski Instytut Naukowy w Ameryce, Jan Lechoń, Kazimierz Wierzyński. Studia o wybranych zagadnieniach działalności 1939-1969. Warszawa 2013, s. 190-191.

$7 \quad$ Z listu do Landauera $\mathrm{z}$ datą 19 III 1940 można się dowiedzieć, że Wittlin mieszkał wówczas pod adresem: 54, rue de Bassano, Paris VIII e. Walter La n d a u e r (1902-1944), którego Wittlin poznał razem z Kestenem w Berlinie, był w latach 1933-1944 pracownikiem wydawnictwa Allert de Lange działającego w Amsterdamie. W wydawnictwie tym Wittlin w 1936 r. wydał Sól ziemi. Publikacji utworu towarzyszyła korespondencja Wittllina z Landauerem trwająca od 1936 do 1940 roku. Zob. Zajączkowski, op. cit.

8 E. Wittlin - Li p t o n, $Z$ dnia na dzień. Reportaż z moda w tle z czasów zawieruchy. Przeł. L. M a cMilla n. Torun 2012, s. 138. W liście do M. Kridla z 2 XI 1941 J. Wittli n pisał: „Czekałem na moją rodzinę 9 miesięcy, z czego trzy pierwsze były najgorsze, bo nie wiedziałem, czy żyje” (Bibl. Uniwersytetu Rzeszowskiego. Archiwum Cyfrowe Józefa Wittlina; stąd pochodzą wszystkie cytowane tu listy Wittlina do Kridla). Żona i córka najpierw znalazły gościnę w Stawiskach u Iwaszkiewicza, a później dzięki staraniom Wittlina uzyskały wizy francuskie. Ich droga wiodła $z$ Warszawy do Berlina, następnie dwa dni zatrzymały się u Stefana Askenazego w Brukseli, a stamtąd udały się do Paryża. „Przyjechały przez Belgię, ale miałem dla nich również i wizę włoską, czego nigdy nie zapomnę Pańskim rodakom, którzy w sposób naprawdę wzruszający szli mi na rękę i w Paryżu, i w Rzymie"- zauważył J. Wittlin w liście do G. Mavera z 17 VII 1949 (zob. J. St a rn a w ski, 
Wittlin współpracował też z założonym przez Mieczysława Grydzewskiego pismem

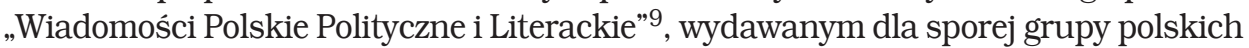
uciekinierów. W stolicy Francji mieszkali wówczas m.in. Słonimscy, Wierzyńscy, Sakowscy, Bormanowie i Stanisław Baliński, dla których miejscem spotkań stała się kawiarnia „Régence”. Kraj nad Sekwaną sprawiał wrażenie bezpiecznego: „Paryż. Zima 1940. Przekonanie, że Niemcy nie atakują, że siedzą cicho ze strachu przed potęgą Francji” ${ }^{10}$. Stopniowo jednak napięcie rosło. Zaczęto rozdawać maski gazowe, a „9 czerwca 1940 r. tanki niemieckie ukazują się nad Sekwaną"11. Gdy klęska Francuzów stała się oczywista, Wittlinowie, podobnie jak wielu Polaków i obywateli innych krajów, chcieli przedostać się do Anglii. Dlatego rankiem $29 \mathrm{~V}$ przybyli do Biarritz, aby następnie z Saint-Jean-de-Luz popłynąć statkiem do Zjednoczonego Królestwa. Pisarz zanotował wtedy ambiwalentne uczucia: radość w związku ze spotkaniem licznych uchodźców z Polski i znalezieniem się na krótko w „polskim” mieście, a zarazem przygnębienie $z$ powodu panicznego egoizmu, który ogarnął uciekinierów. Stąd też literacki zamiar:

Opisać popłoch i święty żar egoizmów - którym zapłonęli ludzie. Byli nieprzytomni jakby pijani miłością własną. Najlepsi przyjaciele przestawali się znać, nie poznawali siebie [...]. Ta miłość zaślepiła ich do tego stopnia - że nie widzieli najbliższych przyjaciół ${ }^{12}$.

Na angielski statek wojenny zaokrętowali się głównie alianccy żołnierze. Fakt, że Wittlinom nie udało się wyjechać do Anglii, stał się punktem zwrotnym w ich życiu. Było to „około 22 czerwca”13. Dlatego nie przypadkiem francuska miejscowość nad Zatoką Biskajską tak często powraca we wspomnieniach pisarza. Od tego momentu rozpoczęła się dla całej rodziny półroczna wędrówka po Europie. Wittlinowie utrzymywali się po części z honorariów, jakie pisarzowi wypłacały zachodnie wydawnictwa za Sól ziemi, po części z pomocy charytatywnej (Stanisław Kot prze-

Listy Józefa Wittlina 〈1896-1976〉 do Giovanniego Mavera 〈1891-1970〉. „Rocznik Biblioteki Naukowej PAU i PAN w Krakowie" 2006, s. 556).

9 Była to pierwsza emigracyjna mutacja „Wiadomości Literackich”. Pismo, pod nominalną redakcją Zygmunta Nowakowskiego, stało się głosem piłsudczyków. Ukazywało się od 17 III do 23 VI 1940 w Paryżu, gdzie związali się z nim skamandryci (tytułem odsyłało do „Wiadomości Polskich” wydawanych w stolicy Francji w latach 1854-1861 pod redakcją Feliksa Wrotnowskiego, Juliana Klaczki i ks. Waleriana Kalinki). Miało ono kontynuację w Londynie do r. 1944, gdy zostało zawieszone przez władze brytyjskie. Reaktywowano je w 1946 r. jako „Wiadomości”.

Wittlin, Raptus Europae, k. 9.

Ibidem, k. 58-59.

Ibidem, k. 27.

13 Pisze o tym Wittlin - Lipt on (op. cit., s. 149): „Czekanie na okrętowanie przeciagało się w nieskończoność. Tymczasem niecierpliwy tłum gęstniał, a deszcz nie przestawał padać. [...] Wszyscy drżeliśmy, że na brytyjskich okrętach nie starczy miejsca, a nawet jeśli uda się na nie dostać, to uderzy w nie torpeda. Przede wszystkim jednak obawialiśmy się, że Niemcy dotrą do portu, jeśli czekanie potrwa zbyt długo. Nasze lęki okazały się uzasadnione, gdy trzeciego dnia, około 22 czerwca, rozpętało się prawdziwe piekło. Okręty nie mogły już dłużej zwlekać. Najpierw do szalup zapakowano wojskowych $\mathrm{z}$ rodzinami i gdy wreszcie przyszła kolej na nas, oświadczono nam, że na statku nie ma już miejsca. Tłum napierał, ludzie krzyczeli, chcąc dostać się bliżej rozchybotanych łódeczek. W tym zamieszaniu rozgorączkowany polski żołnierz, ku skrajnemu przerażeniu moich rodziców, chwycił jedną (może dwie) ze skórzanych walizek ojca i cisną bagażem w wodę, grzmiąc, że "nadbagaż jest niedozwolony“. Waliza (czy też walizy) zawierała szczegółowe notatki i szkice ojca do kontynuacji trylogii Powieść o cierpliwym piechurze, której Sól ziemi stanowiła zaledwie jedną część”. 
kazał Wittlinowi spora kwotę), a później też z zasiłków rządu londyńskiego. Aby uniknać osadzenia w obozie internowanych w pobliskim Pau, Wittlinowie wraz z grupa polskich urzędników i wojskowych z Saint-Jean-de-Luz pojechali samochodem ciężarowym Polskiego Czerwonego Krzyża do Lourdes (była to wówczas baza przerzutowa do Hiszpanii, skąd Polacy podejmowali próby przedostania się do wojsk polskich na Zachodzie lub opuszczenia Europy ${ }^{14}$ ), gdzie przybyli około 10 VII. Zjawiła się tam elita polskiego uchodźstwa: arystokracja polska, prymas August Hlond, Wierzyńscy, Paczkowscy, Micińscy... Odbywały się nawet wieczory literackie, organizowane przez Wacława Grzybowskiego (niedawnego ambasadora Polski w Moskwie). Pobyt ten Wittlin wspominał ze szczególnym sentymentem w liście z 11 IX 1958 do Jana Winczakiewicza:

Znam bardzo dobrze strony, w których Państwo spędzili wakacje. Cały lipiec i początek sierpnia 1940 r. spędziłem z rodziną sprowadzoną z Polski - w Lourdes. Było to wtedy brudne, przepełnione uchodźcami różnych narodowości i kondycji i wygłodzone [miasteczko]. A jednak od groty na wzgórzu Massabelle szła nadzieja na ocalenie. W tym samym czasie przebywał w Lourdes Franz Werfel, autor najpiękniejszej chyba książki o św. Bernadecie. Zna ją Pan. Na pamiątkę owego pobytu naszego w Lourdes i wszystkiego, co było potem, moja córka otrzymała przy bierzmowaniu, tu w Nowym Jorku, trzecie imię Bernadetty. Niechaj to drogiego Pana nie dziwi. Ona zna i czuje swoje pochodzenie ${ }^{15}$.

W lecie 1940 Wittlinowie przyjechali do Nicei, zaproszeni przez daleką kuzynke pisarza, która prowadziła tam pensjonat. Miasto było niemal idylliczne: „Bez smrodu benzyny. Urocza cisza. Dorożki z rozpiętymi baldachimami. Frywolni dorożkarze" 16 . W Nicei znaleźli się też liczni Polacy, których wojna zastała na Zachodzie i którzy nie zdołali ewakuować się do Anglii - m.in. Zdzisław Czermański oraz dyplomata Ignacy Matuszewski z żonami (żona Matuszewskiego była Halina Konopacka), Samuel Tyszkiewicz, Marian Dąbrowski (dziennikarz, największy potentat prasowy okresu międzywojennego, poseł na Sejm II RP) Tadeusz Katelbach, Aleksander Heiman-Jarecki. To miejsce i czas tak wspominała Maria Danilewicz-Zielińska:

Poznałam Wittlinów w lipcu 1940 w Nicei, na Riwierze, w przepychu lata, które - jak słoneczny wrzesień 1939 - kojarzy się we wspomnieniach z najczarniejszymi okresami wojny. Uchodźcy wojenni, którym nie udało się ewakuować do Anglii w czerwcu, miotali się między granicą hiszpańską, Marsylią i granicą włoską w nadziei wydostania się z Francji, zanim załamie się fikcja określana nazwą „zone libre" Petein'a. [...] Byliśmy ślepi na piękno krajobrazu, bez pieniędzy, w stałym poszukiwaniu dachu nad głową i groszowych zarobków. [...] Brak żywności dawał się odczuwać dotkliwie; przed sklepikami w starej Nicei stało się w kolejkach przez długie godziny; brudny łamany ryż sprzedawany na poślad dla drobiu bywał często podstawa posiłków. [...] Było to jedno wielkie i jak najbardziej autentyczne „czekanie na Godota”, co w przekładzie na prozę znaczyło - wizy, umożliwiające opuszczenie Francji. Nie przychodziły. [...] Jeden tylko człowiek (a w tym kontekście „człowiek” ma pełną pozytywną wartość tego terminu) nie załamał się, bladł może tylko i mizerniał. Był nim Wittlin. Obserwowaliśmy go z podziwem, posądzając naprzód o niedocenianie grozy sytuacji, to znów o żelazną siłę woli. A on - był po prostu soba, jakimś rezerwuarem spokoju i franciszkańskiej dobroci ${ }^{17}$.

Sporo informacji na temat sytuacji Polaków na terenach podległych rządowi Vichy zawiera artykuł A. N o s s o w s k i ej $Z$ dziejów pomocy polskim żotnierzom i uchodźcom przebywajacym we Francji $w$ czasie II wojny światowej („Słupskie Studia Historyczne” nr $16\langle 2010\rangle$ ).

15 Muzeum Literatury im. A. Mickiewicza w Warszawie. Korespondencja J. Wittlina z J. Winczakiewiczem, sygn. 4154.

16 Wittlin, Raptus Europae, k. 47.

17 M. Danilewicz-Zi elińs ka, Prozaik czy poeta? „Wiadomości” 1973, nr 50.

\section{http://rcin.org.pl}


Wittlin chciał tu zostać, ale za namową ministra Matuszewskiego, a przede wszystkim - Kazimierza Wierzyńskiego oraz Kestena, podjął decyzję, by jechać dalej. Dzięki tzw. l'orde militaire (rozkazowi wyjazdu do Vichy) udało mu się zdobyć dokumenty potrzebne, by opuścić Francję ${ }^{18}$. Później, obawiając się, iż trafi do obozu pracy, ukrywał się przez krótki czas w angielskim szpitalu w Marsylii ${ }^{19}$. Wreszcie, po otrzymaniu prawa pobytu w Chinach, Wittlinowie mogli dostać wizę tranzytową do Portugalii ${ }^{20}$. Wtedy właśnie, w październiku 1940, nastapiła ich „Ucieczka z Francji. Podróż koleją Nicea-Tuluza"21, skąd odbyli ponowny przejazd do Lourdes, a potem do hiszpańskiej granicy, która przekroczyli w Canfranc $23 \mathrm{X}^{22}$. Ostatnim miejscem postoju we Francji było Biarritz. 12 VI 1970 Wittlin pisał do Zygmunta Haupta:

Czytałem z przyjemnością Pańskiego Diabła baskijskiego - ale nasze doświadczenia wojenne z Baskami były raczej dobre. Gdy byliśmy w Biarritz, a Niemcy już tam się zbliżali i trzeba było wiać, tamtejsza ludność, bardzo życzliwie usposobiona wobec Polaków, okazała nam wiele pomocy i serca. Pewna episjerka chciała nawet „przechować” na czas wojny naszą córeczkę i zaopatrzyła nas gratisowo na drogę. Po wojnie prosiłem znajomą Francuzkę, żeby ją odnalazła i oddała jej od nas upominek. Była z nią wzruszająca korespondencja ${ }^{23}$.

Pierwszy postój w Hiszpanii miał być w Saragossie. Tu jednak zdarzyła się niemiła niespodzianka. Tak opowiada o wydarzeniu córka pisarza:

Nazwisko mojego ojca widniało na liście poszukiwanych, ponieważ, chyba poprzez PEN Club, podpisał on protest po śmierci Federica Garcii Lorki, a za to groziło nawet rozstrzelanie. Oto znamienne zapamiętane przez mnie zdarzenie: chcieliśmy przenocować w Saragossie i najpierw dali nam klucze od pokoju, a potem popatrzyli na listę i kazali je oddać, tłumacząc, że nie mają wolnych miejsc (mój ojciec miał w paszporcie legitymację PEN Clubu podpisaną przez Romain Rollanda). W tym przypadku nie chodziło o pochodzenie mojego ojca (generał Franco nie prześladował Żydów), tylko o jego poglądy ${ }^{24}$.

Pomoc w tym okazał Varian Fry (1907-1967) amerykański dziennikarz, który w czasie drugiej wojny światowej kierował siecią pomocy dla uchodźców. Umożliwił przyjazd do USA wielu artystom. Ten mało znany epizod J. Wittli n wspominał w liście do J. Sakowskiego 19 VIII 1951 (pomylił jednak miesiąc pobytu w Marsylii - zapewne był to lipiec lub sierpień): „Tak, Mój Kochany - pamiętam naszą wspólną Marsylię [...], chociaż był to miesiąc maj w r. 1940 - gdzie musiałem się ukrywać przez parę dni w angielskim szpitalu” (Bibl. Uniwersytetu Rzeszowskiego. Cyfrowe Archiwum Józefa Wittlina). Wyjaśnienie tych okoliczności i ówczesną sytuację Polaków we Francji J. W it tli n opisał po przybyciu do Nowego Jorku: „Muszę powiedzieć, że w czasie mojego pobytu w poczerwcowej Francji, postępowano z Polakami na ogół oględnie, a do tzw. obozów pracy, ustanowionych w połowie września 1940 r. brano tylko tych, którzy korzystali z zasiłków francuskich instytucji opieki społecznej. Najgorzej było w Tuluzie, gdzie urządzano na ulicach obławy na Polaków płci męskiej i w wieku mniej więcej wojskowym, słynne pociagi marsylskie skłaniały naszych ludzi do najbardziej wymyślnych forteli. Ludzie mniej pomysłowi siedzieli w domu i nie pokazywali się na ulicy. Wszystko to było mocno upokarzające i niewesołe” (Wieczyste skarby kultury polskiej. „Nowy Świat” 1941, nr z 6 IV).

Pomocny był tu Adolf Kon - postać dość tajemnicza: Honorowy Konsul Haiti, używający też jeszcze kilku innych nazwisk i tytułów.

21 Wittlin, Raptus Europae, k. 49.

22 Zob. ibidem, k. 30: „Opuszczaliśmy Francję, gdy stary Petain spotykał się z Hitlerem w Montoire” spotkanie to odbyło się właśnie 23 X 1940.

23 Bibl. Uniwersytetu Rzeszowskiego. Cyfrowe Archiwum Józefa Wittlina. Korespondencja Z. Haupta i J. Wittlina.

24 „Mój ojciec żył pisaniem, ono go pochłaniało”, Z E. Wittlin-Lipton rozmawia W. S. W o c ł a w. W zb.: Etapy Józefa Wittlina. Red. W. Li gę z a, W. S. W o cła w. Kraków 2014, s. 242-243.

\section{http://rcin.org.pl}


Następnie Wittlinowie udali się do Madrytu (gdzie przebywali przez tydzień w Pensión Mora), a stamtąd do Lizbony. Do stolicy Portugalii dotarli 31 X, jak świadczy wzmianka w liście do Kestena ${ }^{25}$. Znajdowało się tam wielu Polaków pragnacych wyjechać za ocean. W czasie oczekiwania na wizę amerykańską córka Wittlina dostała zapalenia wyrostka i musiała poddać się operacji ${ }^{26}$. Wittlinowie pozostawali wówczas na utrzymaniu Rządu RP na Uchodźstwie $z$ siedzibą w Londynie, ale wsparcie finansowe wpływało nieregularnie. Bardzo pomocny okazał się Kesten - m.in. wystarał się on o umieszczenie nazwiska Wittlina na liście Thomasa Manna $z$ ramienia American Rescue Committee, która to organizacja gwarantowała zaopiekowanie się uchodźcami i słała im wsparcie. Dzięki zapobiegliwości Kestena otrzymali Wittlinowie 8 I 1941 upragnione wizy amerykańskie i bilety okrętowe. 13 I 1941, w ostatnim do niego liście przed odpłynięciem do Nowego Jorku, Wittlin złożył bardzo osobiste wyznanie:

Moje uczucie lęku przed Ameryka jest mimo wszystko duże - nie mam pieniędzy, nie mówię po angielsku, jestem stary i zmęczony. Ale trzeba też coś zostawić Bogu, i byłby to grzech w ratowaniu mojego dziecka, gdybym nie ufał łasce Bożej.

Wreszcie przyszedł traumatyczny, pełen niepewności dzień opuszczenia Europy utrwalony w notatce:

17 I 1941 S.S. „Siboney”. Lizbona - zdechła mewa na Tagu - symbol Europy. Unikanie spojrzenia na pas ratunkowy zawieszony nad moim łóżkiem. Boję się patrzeć na napisy wskazujące na wyjście na pokład, skąd jest Boat Embaracation. Strach przed dzwonem, na którego dźwięk wszyscy mają wyjść na pokład. Grozę podnosza pozory salonów, haków, eleganckich klatek schodowych. Wszystko się kołysze. Na pokładzie w obliczu bałwanów groza się zmniejsza ${ }^{27}$.

\section{Na następnej stronicy manuskryptu Wittlin dodał:}

Odjazd $z$ Lizbony: Nie pierwszy to raz zdejmują trap z okrętu odpływającego $z$ emigrantami, ale 17 I 1941, gdy „Siboney” wolno, ledwo dostrzegalnie odpływał od Cais Rocha, mieliśmy wrażenie, że jest to coś nieodwracalnego, coś jakby odcięcie pępowiny od łona matki. Patetyczność tego momentu. Jeszcze $1 / 2$ godziny widzieliśmy ludzi na wybrzeżu, którzy nas żegnali, ale my należeliśmy już do innego świata - do Nowego. Jeszcze telefonowaliśmy ze statku w porcie do miasta. Mijaliśmy Belem² ${ }^{28}$.

2 XI 1940 J. Wittlin pisał do H. Kestena: „Od trzech dni jestem w Lizbonie, gdzie udało mi się dotrzeć z Nicei po trudnych perypetiach z moją żoną i córką. Przybyłem tu przymuszony przez telegram od Pana i Pana Schneidermanna, wysłany do mnie stąd do Nicei”.

Okres ten wspominała H. Wittlin w wywiadzie udzielonym A. Frajlich-Zając, noszącym tytuł Skamandryci $w$ Nowym Jorku (maszynopis został mi udostępniony przez A. Frajlich-Zając): „Tam już było trochę przyjaciół: Malczewscy, Czermańscy. I jeszcze Wierzyńscy mieszkali u Państwa Strzeleckich. Tak, że już było całe grono znajomych [...]. Mieszkaliśmy najpierw w kosztownym hotelu, potem w mniej kosztownym pensjonacie, a potem mieliśmy tzw. pokój przy rodzinie i tam byliśmy do końca. Właściwie najgorsze przeżycie emigracji, nim dostaliśmy się do Ameryki, to była niespodziewana choroba mojej córki, która nagle w nocy dostała ostrego zapalenia ślepej kiszki. I trzeba było - to było przed antybiotykami - operować ją natychmiast. Ja nie miałam telefonu, więc pobiegłam o drugiej w nocy do znajomych, uchodźców. Ci ludzie byli zamożni, mieli telefon, polecili mi lekarkę. Kiedy wróciłam do domu, znalazłam w torebce dwa tysiące eskudów, których przedtem tam nie było. Więc właściwie, jeżeli ludzie wierza, że kiedy Pan Bóg chce pomóc, przysyła dobrego człowieka... To tak się stało".

Ibidem, k. 20. 
Wittlinowi nie chodzi jednak tylko o suche fakty. Próbuje zrozumieć ich głębszy sens, osadzić je w historii zbawienia, nadać im biblijny rozmach, gdyż Raptus Europae miało być „próbą legendy” 29 . Dlatego swój los ocaleńca pisarz odczytuje w kategoriach historii Noego:

Właściwie to jest podłe uczucie - widzieć dookoła siebie zagłade - a samemu być ocalonym. Jaką wartość ma dla Noego zatopiony świat? Czy warto jeszcze żyć na świecie, który już nie istnieje. Wstyd być „lepszym człowiekiem”, mieć względy na statku, podczas gdy cała ludzkość ginie w męczarniach. Czy te męczarnie nie wywyższają grzeszników, nikczemników, łotrów ponad spokojnego i „sprawiedliwego", który ma czyste sumienie? Jakże się znalazł Noe wobec ogromu ich cierpień? Czy nie obudziło się w nim poczucie ludzkiej solidarności? ${ }^{30}$

\section{W Nowym Jorku}

Pod koniec stycznia lub 1 II 1941 Wittlinowie przypłynęli do Nowego Jorku³1. W porcie czekali na nich m.in. Kestenowie oraz dziennikarz Peter Yolles, redaktor „Nowego Świata”. Pomoc pisarzowi i jego rodzinie zaoferowały zwłaszcza osoby związane $z$ nowojorską prasa polonijną, np. Maksymilian Węgrzynek, biznesmen i wydawca „Nowego Świata”, czy Szymon Kamiński, redaktor „Robotnika”. Duże znaczenie dla Wittlinów miało także stypendium rządu londyńskiego otrzymywane za pośrednictwem Polish Information Center. List powitalny do Wittlina wystosował 5 II Arthur P. Coleman ${ }^{32}$, który też potem zadbał o zaistnienie pisarza i jego twórczości w środowisku amerykańskim.

Podróż do Ameryki była trudna. Wittlinowie przypłynęli do Hoboken, omijając Ellis Island (dlatego pisarz później wspominał, że nie zobaczył Statuy Wolności). Wynajęto im pokój ze wspólną łazienką przy 69 Ulicy, niedaleko Central Parku ${ }^{33}$. Wkrótce jednak, ponieważ Wittlin nie znosił hałasu, rodzina przeniosła się do niewielkiego domku w Nyack, około $40 \mathrm{~km}$ od Manhattanu. Po niezbyt długim pobycie $\mathrm{w}$ tym miejscu Wittlinowie osiedlili się w Riverdale (w zacisznym porcie Bronxu nad rzeką Hudson), przy Independence Avenue. Ich sąsiadkami były dwie starsze kobiety z Południa, z którymi konwersacje stały się dla Wittlina początkiem nauki angielskiego. Stąd jakiś czas później przenieśli się do dwupokojowego mieszkania w tej samej okolicy, przy 5400 Fieldston Road, lokal 43C ${ }^{34}$. Był to już ostatni adres pisarza w Ameryce.

Pierwszą wizytę w Nowym Jorku Wittlinowie złożyli w redakcji „Nowego Świata”,

Ibidem, k. 92.

Ibidem, k. 64.

W prasie polonijnej fakt ten przeszedł bez echa (podczas gdy pisano o przybyciu Wierzyńskiego i Tuwima). Daty przypłynięcia do Nowego Jorku nie ma również w korespondencji pisarza.

Był to pierwszy Amerykanin niesłowiańskiego pochodzenia, który w 1925 r. otrzymał doktorat ze slawistyki, a w r. 1928 został mianowany wykładowcą Uniwersytetu Columbia; poświęcił się nauczaniu języka polskiego i tłumaczeniom.

Pierwsze miejsce pobytu tak opisuje Wittlin-Lipton (op. cit., s. 221): „Zabrano nas do typowej nowojorskiej kamienicy przy Sześćdziesiątej Dziewiątej Zachodniej pod numerem 62, pomiędzy alejami Central Park West i Columbus. Pokój z alkową na parterze, gdzie się zatrzymaliśmy, był ciemny, ale ciepły, a w łazience na końcu korytarza nie brakowało gorącej wody. Pobliski Central Park przywitał nas szarymi, w przeciwieństwie do europejskich rudzielców, wiewiórkami”.

Zob. ibidem, s. 256-257. 
z którym autor Soli ziemi nawiązał współpracę, zamieszczając na jego łamach swoje artykuły. Sytuacja Wittlina była jednak od początku bardzo złożona, od razu bowiem wszedł w elitarne środowisko, skupiające ludzi polityki i kultury, pisarzy polskich i zagranicznych ${ }^{35}$ :

W czasie wojny znaleźli się [...] [w amerykańskiej metropolii] liczni pisarze i artyści języka niemieckiego z Austrii, Węgier i Niemiec. Było to bardzo specyficzne środowisko, jakby dalszy ciag monarchii habsburskiej i Niemiec weimarskich, z takimi nazwiskami, jak: Hermann Broch, autor Śmierci Wergilego, czy Béla Bartók ${ }^{36}$.

Wittlin uczestniczył w życiu kulturalnym Polonii, biorąc udział w wieczorach autorskich, w rozmaitych wydarzeniach literackich oraz licznych spotkaniach. Ukazywały się także jego teksty publicystyczne i utwory poetyckie. Jednym z pierwszych wystapień pisarza (przedstawianego przez „Nowy Świat” jako „oficjalny polski kandydat do Nagrody Nobla”), które miało miejsce 25 II 1941 w Kole Polskim w Nowym Jorku ${ }^{37}$, był wykład Wieczny skarbiec kultury polskiej, poświęcony głównie znaczeniu twórczości Mickiewicza dla Polaków ${ }^{38}$. $15 \mathrm{~V}$ Wittlin przemawiał jako reprezentant Polski na bankiecie inauguracyjnym Europejskiego PEN Clubu w Ameryce $^{39}$. $22 \mathrm{~V}$ wygłosił mowe otwierająca przyjęcie powitalne $\mathrm{w}$ International Institute na Brooklynie, wydanym $\mathrm{z}$ okazji przyjazdu Juliana Tuwima. W podobnej roli wystąpił 5 VI, gdy Polski Klub przy Uniwersytecie Columbia urządzał przyjęcie z racji przybycia Wierzyńskiego. Wkrótce w Klubie tym odbyły się serie wykładów poświęcone współczesnej literaturze polskiej. Zainaugurował je Wittlin wystapieniami 7, 8, 9 i 10 VII 1941. Na spotkaniu zorganizowanym przez The National Arts Club 28 XI tegoż roku wygłosił z kolei przemówienie o Soli ziemi podczas śniadania ku czci autorów zagranicznych, których książki zostały opublikowane w Ameryce. Dzień później w Konsulacie Generalnym na Manhattanie odbyła się Wieczornica Literacka $z$ udziałem Wittlina, Tuwima oraz Jana Lechonia (było to pierwsze publiczne wystapienie Koła Pisarzy z Polski, zapowiadające ich wspólną działalność), a 1 XI 1941 ukazało się inauguracyjne wydanie „Tygodniowego Serwisu Literackiego Koła Pisarzy z Polski”, który od numeru 6, czyli od 10 XII wychodził jako „Tygodniowy Przegląd Literacki Koła Pisarzy z Polski” ${ }^{40}$. Oba periodyki, o niewielkiej

N. Tay lor - Te r le c k a, Józefa Wittlina pierwsze kroki na Nowym Kontynencie. W zb.: Literatura polska obu Ameryk. Studia i szkice. Seria 1. Red. B. Now a cka, B. Szała sta-Rogowska. Katowice-Toronto 2014.

Cz. Miło s z, Mój Wittlin. „Dekada Literacka” 2001, nr 5/6, s. 75.

Siedziba Koła Polskiego była w Konsulacie Generalnym RP w Nowym Jorku pod adresem 151 E 67 St.

Na początku J. Wittli in z dumą wyznał to, co często powtarzał: „Mam zaszczyt należeć do starej rodziny, której protoplastą był Mikołaj Rej z Nagłowic. Jestem, a przynajmniej czuję się, ubogim krewnym tej literatury”. Jego słowa zostały opublikowane w nowojorskim „Nowym Świecie” (1941, nr z 6 IV). Prawdopodobnie jeszcze wcześniej pisarz wystąpił na spotkaniu z Polonią, na którym zaprezentował esej Płaszcz (o czym wspomina H. Wittlin w przywoływanym już tu wywiadzie). Czas i miejsce tego wystąpienia trudno jednak ustalić.

Przemówienie Wittlina do Polaków w kraju z wieczerzy PEN Clubu w New Yorku. „Nowy Świat” 1941, nr z 22 V. Organizację tę założył znany francuski pisarz, Jules Romains (1885-1972), a Wittlin zasiadał w jej prezydium.

„Tygodniowy Przegląd Literacki Koła Pisarzy z Polski” ukazywał się pod takim tytułem do końca 1942 roku. Jego kontynuacją był „Tygodnik Polski”, którego pierwszy numer nosi datę 10 I 1943, 
objętości, drukowane na powielaczu, miały głównie charakter literacki, a ich celem było dostarczanie materiałów dla polskich redakcji prasowych w Stanach Zjednoczonych. Wittlin od początku był w składzie redakcyjnym ${ }^{41}$. Był też nadał publicystą „Nowego Świata” oraz „Robotnika Polskiego”, gdzie zamieścił szereg różnych tekstów, które nigdy nie zostały przedrukowane ${ }^{42}$. 3 VIII 1941 Coleman z satysfakcją i nadzieją witał poetę na łamach „Saturday Review of Literature”. Pisał m.in.

Człowiekowi pokroju Wittlina, który przywykł życie traktować jako odyseję pełną ślepych, a przecież celowych zmagań, przeraźliwe zdarzenia wstrząsające światem nie wydają się niczym niezwykłym. Patrzy on na nie $z$ wyżyn swojej prawie mnisiej abnegacji, do której doszedł przez lata studiując Homera i Biblię, wmyślając się w życie św. Franciszka z Asyżu. [...] Należy się spodziewać, że Wittlin znajdzie w Nowym Jorku oazę milczenia, że dokończy tutaj właśnie Powieść o cierpliwym piechurze, a także stworzy wielkie dzieło na temat „wędrówki ludów” dwudziestego wieku. Nikt nie posiada lepszych po temu kwalifikacji niż Wittlin, ponieważ kocha i zna Europę na wylot i wierzy niezłomnie w „europeizm”, może ponadto pokazać Ameryce, dość sceptycznej w tej chwili, dobro i piękno kryjące się na dnie tego wyświechtanego pojęcia ${ }^{43}$.

Prognozy Colemana nie w pełni się ziściły. Już w 1942 r. współpraca Wittlina Z „Nowym Światem” wyraźnie osłabła, później zaś zupełnie zanikła44. Było tak zreszta nie tylko w jego przypadku. Systematycznie publikowany w tym periodyku w latach 1941-1942 „Niedzielny Dodatek Literacki”, prowadzony przez Koło Pisarzy z Polski, najpierw utracił najbardziej rozpoznawalnych autorów (Lechonia, Tuwima, Wierzyńskiego i Zenona Kosidowskiego), a od 1943 r. w ogóle przestał się ukazywać ${ }^{45}$. Wittlin (mimo chorób) nie zrezygnował jednak z udziału w życiu literackim. Doznawał często stanów depresyjnych, ale występował na wieczorach literackich,

a ostatni 22 VI 1947 (gdy pismo zostało zamknięte z powodu trudności finansowych). W roli nominalnego redaktora występował T. Szybel. Tygodnik był subsydiowany przez amerykańskie koła polonijne oraz Ministerstwo Informacji polskiego rządu emigracyjnego Władysława Raczkiewicza w Londynie i popierał jego politykę. Początkowo Wittlin był w redakcji tego periodyku (obok Lechonia, Kosidowskiego i Wierzyńskiego), jednak rosnące różnice zdań między nim a Lechoniem spowodowały, że w końcu tylko ten ostatni go prowadził, a Wittlin ostatecznie wycofał się od września 1943 (od numeru 37). Niemniej współpraca wspomnianych pisarzy zaowocowała utworzeniem w latach czterdziestych w Nowym Jorku drugiego po Londynie polskiego ośrodka literackiego za granicą. Zob. J. Ś w i ę c h, Literatura polska w latach II wojny. Wyd. 6, 2 dodruk. Warszawa 2010, s. 326-328, 386, 448, 473, 572.

41 Zob. I. J. Ka mińs ki, Wittlin z kresów. W: Polska literatura emigracyjna. Red. W. Biała si ewicz. Lublin 1983, s. 143-150.

42 Wśród nie przedrukowanych nigdy tekstów pisarza są wiersze i eseje publikowane w „Nowym Świecie”. Utwory poetyckie to: Ból drzewa (1941, nr z 12 IV), Matka żegnajedynaka (1941, nr z 8 VI), Oda na cześć mowy i poezji polskiej (1941, nr z 14 XII), Pieśń wigilijna o Mickiewiczu (1941, nr z 21 XII), Tren XX (1942, nr z 13 XI). Eseje zaś to: Wieczyste skarby kultury polskiej (1941, nr z 6 IV), Dokad chciatbym wrócić? (1941, nr z 23 XI), Gorzkie uświadomienie. O twórczości w kraju i na emigracji (1941, nr z 30 XI), O „Soli ziemi” (1941, nr z 28 XII).

43 Streszczenie wypowiedzi Colemana ukazało się w artykule A. P. Coleman o Wittlinie (,Wiadomości Polskie" 1942, nr 98).

44 Bodaj ostatni tekst J. Wittlin a na łamach „Nowego Świata” (1943, nr z 10 I, s. 13, 20) to recenzja z polskiego przedstawienia w Nowym Jorku: Jeszcze o „Pastorałce”. Również ten tekst nigdy nie został przedrukowany.

45 Jednak wsparciem dla działań polskich pisarzy był z pewnością założony w $1942 \mathrm{r}$. w Nowym Jorku Polski Instytut Naukowy w Ameryce. Zob. D. S. W and y cz, Polski Instytut Naukowy $w$ Ameryce. W trzydziesta rocznice 1942-1972. Nowy Jork 1974. 
które były dla niego źródłem dochodu. Przez cały czas swego pobytu w Stanach Zjednoczonych dzięki zapobiegliwości żony spotykał się też z polskimi pisarzami Lechoniem, Tuwimem i Wierzyńskim, a także z Anną i Marianem Kisterami, którzy w Nowym Jorku prowadzili wydawnictwo „Roy Publishers” ${ }^{\text {" }}$. To polskie towarzystwo niejednokrotnie spędzało wakacje w Hunter, niewielkim mieście około $200 \mathrm{~km}$ od Nowego Jorku na terenach Gór Catskill. Wittlina zapraszano też na liczne spotkania organizowane przez amerykańskie środowisko literackie, na których jednak nie czuł się dobrze. W dodatku nie chciał uczyć się angielskiego, co, oprócz zamieszkiwania na peryferiach Nowego Jorku, pogłębiało jego izolację. Mimo to odnosił pewne sukcesy. O największym z nich pisał 18 III 1949 do Aleksandra Janty-Połczyńskiego, charakteryzując amerykańską recepcję swej książki, opublikowanej 30 IX 1941 w oficynie „Sherdian House” ${ }^{47}$ :

W roku 1941 - przed samym przystapieniem Ameryki do wojny - przedrukowano tu londyńskie u Mettirera wydanie tłumaczenia Soli ziemi. Moment był nieszczególny (październik 1941) - ale nawet moi najzawistniejsi koledzy musieli przyznać, że chyba żadna polska książka od czasu Chłopów nie była tak gorąco przyjęta przez krytykę w Ameryce i tak szeroko omawiana. Pisał o niej i Tomasz Mann, i najwybitniejsi dziś krytycy powieści: Alfred Kazin (w „Herald Tribune”) i Charles Neider (ten od Tomasza Manna i Kafki), a chociaż sprzedano jej zaledwie 3000 (taki był nakład, a w Anglii były dwa wydania) - otrzymałem za nią w r. 1943 - jako pierwszy Polak - nagrodę Art and Letters Grant - 1000 dolarów, co było dla mnie zupełną niespodzianką i co przedstawiciele ówczesnego rządu w Londynie uznali za sukces narodowy. Byli też obecni na uroczystej ceremonii ${ }^{48}$.

Różnego rodzaju zaangażowania literackie Wittlina wynikały $z$ faktu, że był on zdeterminowany, aby również na wygnaniu pozostać pisarzem, choć oczywiście okazało się to dla niego o wiele trudniejsze niż w Polsce. Warto także pamiętać, że uczestniczył aktywnie w wydaniu dwóch opracowań zbiorowych. Najpierw wraz z Manfredem Kridlem i Władysławem Romanem Malinowskim ${ }^{49}$ przygotował antologię polskiej myśli demokratycznej For Yours Freedom and Ours Democratic Heritage in Poland (New York 1943), z Epilogiem własnego autorstwa, w którym m.in. zwalczał amerykańskie stereotypy o Polakach (np. zarzut antysemityzmu). W roku 1951 wspólnie z Kridlem i Miłoszem wydał z kolei księge pamiątkową Adam Mickiewicz: Poet of Poland. A Symposium (opublikował tam artykuł o Panu Tadeuszu). Ponadto w The Torch of Freedom. Twenty Exiles of History (New York 1943) zamieścił szkic o Kościuszce ${ }^{50}$. Drukował także teksty w „Saturday Review” (1942, nr 4; 1947, nr 24)

„Roy Publishers” to emigracyjna kontynuacja działającego w Warszawie w latach 1924-1939 Towarzystwa Wydawniczego „Rój”, którego współwłaścicielem i dyrektorem był M. Kister.

Obszerna anglojęzyczna recenzja książi Wittlina, autorstwa Z. J. Sł u s z k a: Tale of the Unknown Polish Soldier, ukazała się w „Nowym Świecie” (1941, nr z 5 X).

Bibl. Narodowa w Warszawie. Archiwum Aleksandra Janty-Połczyńskiego, sygn. III 12975, mf. 112262 (stamtąd pochodzi również następny cytowany tu list). Fragment Soli ziemi w tłumaczeniu na angielski: The Emperor and the Devil in „Heart of Europe”, był też opublikowany w Antology of Creative Writing in Europe 1920-1940 (Ed. K. Ma n n, H. Ke s ten. New York 1943). Dwa lata później książka ukazała się także w Filadelfii.

Władysław Roman Malin ow ski (1909-1975) był polskim dziennikarzem i politykiem socjalistycznym, przewodniczaccym Komitetu Zagranicznego PPS w Stanach Zjednoczonych, w okresie drugiej wojny światowej szefem pisma i wydawnictwa „Poland Fights”, popularyzującego w USA wiedzę o Polsce.

Oryginał polski opublikowano w drukowanym w Londynie miesięczniku „Nowa Polska” w 1944 roku. 
i w „Books Abroad”51. Współpracując od r. 1950 z Radiem Wolna Europa, przygotował około 70 felietonów radiowych, tyleż audycji poświęconych głównie polskiej literaturze emigracyjnej oraz kilkadziesiąt recenzji ze spektakli teatralnych w Nowym Jorku. Za oceanem podjął się również trzeciego tłumaczenia Odysei, które ukazało się w Londynie w $1957 \mathrm{roku}^{52}$. $Z$ tego okresu warte odnotowania są też jego rozproszone po świecie listy, których liczbę można oceniać na tysiące (kolekcja korespondencji przedwojennej spłonęła w warszawskim mieszkaniu pisarza w 1939 roku) ${ }^{53}$. Ameryce poświęcił Wittlin 10 esejów, których przedruki zostały zebrane w tomach Orfeusz $w$ piekle XX wieku (1963) ${ }^{54}$ i Eseje rozproszone (1995) ${ }^{55}$. Radio Wolna Europa nadało też 10 jego pogadanek dotyczących literatury amerykańskiej ${ }^{56}$, 4 audycje poetyckie prezentujące wiersze autorów amerykańskich ${ }^{57}$ oraz liczne recenzje ze spektakli teatralnych na Broadwayu ${ }^{58}$. Wiele wzmianek o kraju swego osiedlenia i o innych kwestiach Wittlin pozostawił także w notatnikach. W latach 1971-1975 pisał, nie opublikowany jeszcze, pamiętnik ${ }^{59}$.

51 Joseph Wittlin by Wittlin. „Books Abroad” 1942, Winter. W późniejszych latach na łamach tego właśnie pisma J. Wittli in popularyzował literaturę polską: A Quarter Century of Polish Literature (1927-1952). Jw., 1956, nr 1; Polish Literature: A Post Scriptum. Jw., nr 2, s. 17.

52 Wittlin utwór Homera przekładał od 1912 roku. Dwa jego tłumaczenia ukazały się w latach 1924 i 1931 (pierwsza wersja została wydana we Lwowie przez Alfreda Altenberga oraz Zakład Narodowy im. Ossolińskich, drugą zaś, zmienioną, opublikował w Warszawie Jakub Mortkowicz). Przekład dokonywany w Ameryce pisarz uważał za dzieło swego życia. Istotniejsze Wittlinowskie translacje wierszy ogłosił Z. Ku bia k: Przyjaźnie poetyckie Józefa Wittlina. Warszawa 1995.

Zauważył to P. Kądzi ela (wstęp w: J. Wittli n, Listy do Anny i Jarosława Iwaszkiewiczów. Podał do druku P. Ką dzi ela. „Twórczość” 1997, nr 2, s. 94): „Listy Józefa Wittlina, gdy ukażą się w edycji książkowej, zajmą zapewne poczesne miejsce w szczupłym objętościowo dorobku literackim autora Hymnów. Ułożone chronologicznie, stworzą intelektualną autobiografię pisarza, będą nie tylko kopalnią informacji biograficznych, dokumentem epoki, ważnym przyczynkiem do dziejów emigracji polskiej po 1939 r. i kontaktów wychodźstwa $z$ krajem, lecz również wspaniałym źródłem wiedzy o prywatnych stronach literatury, odsłaniającym niejedną tajemnicę psychologii twórczości literackiej”. Dotychczas wydano niewielką część listów pisarza. Oprócz tego, że są one dokumentem, należą też do literatury.

54 Chodzi o następujące eseje: Płaszcz, Do jakiej Ameryki jechałem, Mój pierwszy rok w Ameryce, Pod znakiem „Kartofli”, Novi Eboraci, Poe w Bronie, Hemingway, śmierć i zabijanie. Należą do nich: Tadeusz Kościuszko, Lorca na scenie nowojorskiej, Teatr amerykański (i zachodnioeuropejski).

56 Pogadanki noszą tytuły: Graham Green - przypadek wypalony, O Bernardzie Bernsonie, O ksiażce Berensona „The Passionate Sightseer”, O ksiażce Filipa Friedmana „Their Brothers Keepers”, American Poet - Robinson Jeffers, O starożytności klasycznej $w$ Stanach Zjednoczonych, Atak na awangardę literacką w Stanach Zjednoczonych, O ksiażce Van Wyck Brookes „Twórcy i odkrywcy. Dzieje pisarza w Ameryce. 1800-1915" (5 tomów), O poecie amerykańskim Carlu Sandburgu, O ksiażce Carla Sandburga o Lincolnie. Komplet materiałów znajduje się w archiwum pisarza w Instytucie Józefa Piłsudskiego w Nowym Jorku. Felietony te zasługują, przynajmniej w części, na publikację. Są to: Przekłady 5 poetów amerykańskich: Karl Shapiro, Wallce Stevens, Robert Frost, William Carols Williams, Conrad Aiken, Marianna Moore; Wiersze Robinsona Jeffersa; Wspótczesna poezja amerykańska i brytyjska według antologii Pawła Mayewskiego; Wspótczesna poezja amerykańska: Auden, Steven Vincent Benét, Eliot, Williams, Merton.

58 Manuskrypty recenzji znajdują się w archiwum pisarza w Muzeum Literatury im. Adama Mickiewicza w Warszawie.

59 Pamiętnik jest złożony w Houghton Library (Cambridge, MA) i będzie udostępniony w r. 2026, czyli 50 lat po śmierci pisarza. 
Największą porcję wiedzy o życiu Wittlina w Ameryce, o jego zainteresowaniach i problemach dają listy, które pozwalają dość dobrze poznać jego losy od momentu przyjazdu do Ameryki, gdzie przybył on jako pierwszy spośród skamandrytów ${ }^{60}$. Powiernikami byli mu zwłaszcza bliscy przyjaciele: Wierzyński, Grydzewski i Tuwim. O swoich amerykańskich doświadczeniach autor Soli ziemi pisał też niekiedy do Kestena, Kridla, Janty-Połczyńskiego, Jerzego Giedroycia i Wiktora Weintrauba. Najwcześniejsze doniesienia Wittlina o jego sytuacji w Stanach Zjednoczonych pochodzą z korespondencji z Kestenem i Wierzyńskim. Pierwszy list, jaki pisarz wysłał po przybyciu do Nowego Jorku, był adresowany 2 II 1941 do Kestena. Znajduje się tam m.in. krótka wzmianka o samopoczuciu nadawcy: „Jestem bardzo słaby po trzech dniach gorączki”. W następnym liście do tego samego adresata, nie oznaczonym datą, Wittlin wyznał:

Ostatni czas w Nowym Jorku był już nie do zniesienia. Od dni jesteśmy tu gośćmi, ale za tydzień jedziemy dalej, a mianowicie do: Clarkstown County Club, Nyack, N.Y., gdzie od 1 czerwca wynajęliśmy letnie mieszkanie. Ostatnio jest nam bardzo źle. Moja żona jest zupełnie wyczerpana, a o mnie lepiej nie mówić. Elżbieta, dzięki Bogu, wyzdrowiała.

W podobnym tonie utrzymane są też listy do Wierzyńskiego. 26 II 1941 autor Soli ziemi opisywał przyjacielowi (gdy ten przebywał z żoną w Brazylii, gdzie oczekiwał na wizę amerykańską) swoją podróż i pierwsze tygodnie w Ameryce:

Jeśli gniewasz się na mnie, że dopiero dziś, przeszło trzy tygodnie po przybyciu do N.J., do Ciebie się odzywam - to powściagnij gniew i przebacz staremu Mendzie [autookreślenie Wittlina - R. Z.], który miał straszną podróż w dormitorium na amerykańskim „Siboneyu” wraz z 49 innymi rzygaczami. Ciagle były burze, raz statek mało się nie wywalił. Podczas jednej z takich burz upadłem nieszczęśliwie i potłukłem sobie ramię, nadwyrężając kość obojczykową tak boleśnie, że przez dwa tygodnie nie mogłem spać i żona musiała mnie myć i ubierać. Po przybyciu do N.J. grypa (tu bardzo zimno), ostatnio znów choruje Elżunia, leży od tygodnia na zapalenie gruczołów po grypie [...]. Tu absolutnie nikt ze sfer polskich ani żydowskich nie zajmuje się naszym losem i zdaje się nie zamierza zajmować nikim, kto przyjedzie. Tu jest się zdanym całkowicie na własną inicjatywę. Najlepiej tym, którzy mają zamożnych krewnych lub przyjaciół. Ja ich nie mam i do tej pory jeszcze grosza nie zarobiłem, a wydałem już 200 dol. z tej reszty, jaka mi została z Funduszu Kultury. Mieszkamy w jednym pokoju z kuchnią, która jest równocześnie łazienką, w której śpi Elżunia. Płacimy za to 9 dol. tygodniowo, co jest bajecznie tanio. Na jedzenie wychodzi nam przeciętnie półtora dolara dziennie, przy czym wszystko gotuje Halina. [...] Jak widzisz, sytuacja nasza przedstawia się niewesoło. Życzę Wam z całego serca, żeby u Was było inaczej, gdy tutaj przyjedziecie. Ale za mój przyjacielski obowiązek uważam Was przestrzec przed pomocą tutejszej Polonii. [...] Amerykanie, z którymi się zetknąłem, raczej mili, mile się do nich rozczarowałem: życzliwi, ludzcy, prości. Użyczą człowiekowi ewent[ualnie] szczęścia. Ale obcowanie z nimi utrudnia fakt, że nie znam angielskiego, kt[órego] będę musiał na gwałt się nauczyćc1.

Lata 1941-1943 były dla Wittlina i jego rodziny szczególnie trudne. $Z$ tego czasu pochodzą najbardziej wstrząsające, pesymistyczne listy, świadczące o tragicznej sytuacji zdrowotnej, finansowej i towarzyskiej pisarza, który, co prawda, udzielał się wtedy w życiu polonijnym i zabiegał o wizy amerykańskie dla przyjaciół z Polski przebywających na emigracji, ale też dużo chorował i zmagał się $z$ trudnościami

60 Wittlin przybył do Ameryki na przełomie stycznia i lutego 1941, Tuwim 7 V, Wierzyński 2 VI, a Lechoń 11 VIII.

61 Biblioteka Polska w Londynie. Archiwum Kazimierza Wierzyńskiego. Korespondencja J. Wittlina z K. Wierzyńskim, sygn. 1360/rks/VI/1t „W”. Tam znajdują się też kolejne cytowane tu listy J. Wittlina do K. Wierzyńskiego. 
bytowymi. Dlatego początkowo Wittlin zamierzał wrócić do Anglii, lecz nie było to możliwe z racji jego słabego zdrowia, braku pieniędzy na podróż i opieki nad 9-letnią córka. Z listu do Kestena datowanego 4 VI 1941 wiadomo, że Wittlinowie mieli już wówczas długi spowodowane chorobami i trudnościami w znalezieniu pracy. Od początku nowojorska metropolia wyraźnie im nie służyła z powodu klimatu, infrastruktury i braku przyjaciół. Niewielkie kwoty pisarz otrzymywał za publikacje w prasie polonijnej oraz w formie stypendiów z Funduszu Kultury Narodowej wypłacanych za pośrednictwem Polish Information Center (na początku pobytu było to 20 funtów, a od stycznia 1943 do sierpnia 1945 - 25 funtów miesięcznie). Trochę zarabiała też jego żona, co jednak nie rozwiązywało problemów rodziny ${ }^{62}$. Być może, najbardziej przygnębiające stwierdzenia zawiera list do Tuwima z 18 VIII 1942:

Ja straciłem już 20 funtów od czasu przyjazdu do U.S.! Ciagle niedobrze. Szukamy [...] nowego mieszkania tutaj. [...] Zapomniałem wszystkich języków, z polskim włącznie. Zapomniałem, że byłem kiedyś pisarzem, zapomniałem, że byłem człowiekiem ${ }^{63}$.

\section{Z kolei w opatrzonym tą samą datą liście do Kridla czytamy:}

Ostatnio pod wpływem trosk i przepracowania moja żona również poważnie niedomaga - ma mocną anemię i musi razem ze mna jeździć 3 razy w tygodniu do lekarza na zastrzyki. Spożywamy ogromną ilość lekarstw, co nas doprowadza do materialnej ruiny. No, ale szczytem naszej mizerii była choroba córeczki, zapalenie płuc, na które zapadła przed kilkoma tygodniami, akurat w dniu projektowanego wyjazdu na wieś.

Dwa miesiące wcześniej, 17 VI 1942, do tego samego adresata Wittlin pisał:

Byłem poważnie chory przez dłuższy czas. Właściwie była to gwałtowna powtórka zeszłorocznych infekcji jelitowo-żółciowych i okazało się, że choroba trawiła mnie przynajmniej od dziesięciu miesięcy - źle leczona i zaniedbana. Ostatnio jestem rekonwalescentem i jakby nowym człowiekiem.

Mimo późniejszej kuracji w St. Francis Health Resort w Denville, w stanie New Jersey, zdrowie Wittlina w następnych latach niewiele się poprawiło. Trudne warunki mieszkaniowe, bieda, choroby, wyczerpanie żony, która głównie utrzymywa-

O ówczesnej sytuacji rodziny mówiła żona pisarza w wywiadzie przeprowadzonym przez $\mathrm{F} \mathrm{r} \mathrm{aj} \mathrm{lic} \mathrm{h} \mathrm{-}$ -Zając:

„A. F.-Z.: Z czego Państwo [...] utrzymywali się przez te pierwsze miesiące?

H. W.: Ja mieszkałam wtedy w Riverdale i tam była taka praca statystyczna, do której nie trzeba było świetnie znać język. Na maszynach obliczało się rezultaty. Następna praca, to już może przeskakuję, pracowałam w takim też amerykańskim Investor's Syndicate. Tam trzeba było obliczać pożyczki hipoteczne, też na maszynce. Pytali się, czy umiem postawić znaki dziesiętne. Powiedziałam, że owszem, że umiem. Ale potem to już była pomoc. To był Polski Instytut Informacyjny, założony przez Rząd Londyński, i oni wypłacali pewne stypendia. Poza tym był "Nowy Świat", tam niby dużo nie płacili. Ale jakimiś cudami tu dostałam trochę pieniędzy, tam trochę pieniędzy... [...]

A. F.-Z.: Czytam w liście Tuwima, że było (gdzieś w październiku 1941 r.) bardzo ożywione życie towarzyskie. Był tutaj Rubinstein, byli państwo Rodzińscy. Na czym ono polegało, jak to wszystko wygląałało, jak Państwo spotykaliście się?

H. W.: Najczęściej spotykaliśmy się u pana Mühlsteina, który był dyplomatą polskim, a potem tutaj przyjechał jako prywatny człowiek. On prowadził wielki salon w Paryżu. Jego córka napisała teraz książkę, Anka Mühlstein. On był ożeniony z córką barona Roberta Rothschilda. Muszę powiedzieć, że w tych najcięższych czasach, jeśli o nas chodzi, to pomoc finansowa pana Anatola Mühlsteina dla nas była nieoceniona. On nam pomagał. Nie ma się czego wstydzić”. 
ła rodzine - to zasadnicze przyczyny jego zniechęcenia i apatii, a tym samym niewielkiej aktywności literackiej. Narzekania na sytuację w amerykańskiej metropolii niemal od początku pojawiały się w korespondencji Wittlina. 1 X 1941 pisał on do Kestena o niskim poziomie intelektualnym poznanych Amerykanów i konstatował: „Powoli degraduję się do poziomu prowincjonalnego nauczyciela - przez co nie chcę powiedzieć, że chciałbym zostać profesorem na amerykańskim uniwersytecie”. Podobne stwierdzenia znalazły się też w liście do Kridla z 6 III 1943:

Nasz pobyt w Nowym Jorku, choćby to był Riverdale, jest właściwie jałowy i szkodliwy. Po prostu marnujemy się tutaj. Atmosfera niespokojna, nerwowa, klimat fatalny. Trzyma nas tutaj nędzna posada mojej żony, która w tych warunkach goni już resztkami sił, wstając o 6-tej rano i siedząc 7 godzin dzienne przy maszynie do liczenia.

Później warunki życia uległy dalszemu pogorszeniu. Szczególnie krytyczny był rok 1945. Zakończenie wojny oznaczało cofnięcie przyznawanych przez kilka lat zasiłków z Funduszu Kultury Narodowej. W liście do Wierzyńskiego z 20 VIII 1945 Wittlin pisał:

Wczoraj otrzymałem od Stachana ${ }^{64}$ list z czekiem na 100 dol., jako odprawę z Funduszu Kultury [...]. Jako ludzie bez stosunków, bez przynależności, nie afiszujący swych sympatii ani antypatii - jesteśmy kompletnie izolowani od wszystkich źródeł nowego życia.

Stale powracały też problemy zdrowotne. Pisarz informował o nich Grydzewskiego 12 IX 1947:

U nas bardzo ciężkie czasy. Odnowiła mi się moja choroba, ta, która mnie unieruchomiła w latach 1941-43. Obecnie dopiero dzięki warszawskiemu lekarzowi, drowi Glassowi, wykryto po uciążliwych badaniach rentgenologicznych jej nikczemne źródło w jelitach. Jest to bardzo rzadki, nieuleczalny feler organiczny, z którym muszę wytrwać: do końca, bo usunąc go nie można. Podobno przyszedłem z nim na świat, a dopiero w późniejszym wieku zaczął mi dokuczać. [...] Jestem inwalidą i tyle ${ }^{65}$.

Wkrótce potem - 20 IX 1947 - na pytanie Grydzewskiego o stan zdrowia, Wittlin uszczegółowił informacje:

Pytasz o moją chorobę w ostatnim liście. Bardzo obrzydliwa rzecz. Zdarza się u dorosłych bardzo rzadko. Nazywa się diverticulosis, od: diverticula, po polsku: uchyłki, które setkami obsiadły mi jelita, podobno z tym się urodziłem. Powoduja potwornie bolesne spazmy, zwłaszcza latem, i inne zaburzenia. Jestem właściwie inwalidą i bardzo żal mi żony ${ }^{66}$.

W archiwum Wittlina w Instytucie Józefa Piłsudskiego w Nowym Jorku zachował się list do nieznanych adresatów (jakiejś zaprzyjaźnionej rodziny), w którym pisarz dokonał bolesnego rozrachunku $\mathrm{z}$ dotychczasowym życiem na emigracji, z żywionymi przezeń złudzeniami. Na ich miejscu wyrosła bowiem twarda rzeczywistość ekonomiczna i polityczna: utrata zapomóg rządu polskiego, niekorzystne zmiany ustrojowe w Polsce, minimalne szanse na powrót do kraju. List nosi datę 1 I 1948:

Rok poprzedni był rekordowo marny z wszystkich naszych ośmiu lat na tej błogosławionej (jak komu) półkuli. Teraz pod koniec roku i z początkiem nowego kroi mi się sporo pracy: tylko że nie ma

Nie udało się ustalić, o kogo chodzi. Prawdopodobnie był to pracownik FKN lub rządu londyńskiego. J. W it tli n, Listy do redaktorów „Wiadomości”. Oprac., przypisy J. Olejni c z a k. Konsultacja edytorska B. Dorosz. Toruń 2014, s. 47-48. Choroba, która dręczyła Wittlina, nosi medyczną nazwę „nadwrażliwość jelita grubego”.

Ibidem, s. 50. 
dość sił na podzielenie jej na prawdziwą pracę literacką, i na szewską robotę zarobkową. Jeśli Państwo mają w Ameryce trudne początki - jest to normalna rzecz, u nas raczej początki były łatwiejsze od tego, co mamy od zakończenia wojny. Nas wszystkich, tj. tzw. intelektualistów polskich, trochę zdemoralizowała wojna i pensje rządu londyńskiego, chociaż nie można powiedzieć, żeby były duże. Zamiast rozejrzeć się w tutejszych, wówczas raczej sprzyjających (zwłaszcza niżej podpisanemu), warunkach egzystencji i pracy, myśmy zamykali oczy na otaczającą nas rzeczywistość amerykańską, żyliśmy, co jest zresztą zrozumiałe, więcej tam, gdzie nas nie było, tj. w kraju, niż tu, gdzieśmy byli. Każdy z nas na swój sposób zbawiał Polskę, aż w końcu stało się to, co się stało. I trzeba było tzw. jubileuszów, żeby trójka poetów: Wierzyński, Lechoń i niżej podpisany, nie zdechła z głodu. Każdemu z nas po kolei grono przyjaciół i znajomych sprawiło jubileusik za biletami po cenach niestałych. Oczywiście wszystkich zakasował, jak zwykle, Lechoń.

Za tym nieco humorystycznym wyznaniem ukrywa się jednak poważny, trwający nieprzerwanie od r. 1941, dramat człowieka, który nie potrafił ani odpowiednio zaadaptować się do nowych warunków, ani zrozumieć amerykańskiej rzeczywistości. Wygnańczy los spowodował, że z biegiem czasu Wittlin pogrążał się coraz bardziej w depresji i pesymizmie. Świadectwem tego sa szczere i bolesne wyznania kierowane do Kestena i Wierzyńskiego. Do autora Zwycięstwa demonów pisał:

Żyję w ciagłej depresji, codziennie czytam w polskich gazetach nazwiska moich przyjaciół, pisarzy, nauczycieli, profesorów - z którymi kiedyś byłem związany, a którzy zostali zamordowani albo zmarli w obozach koncentracyjnych. Wstydzę się żyć. Po prostu całkowicie odwykłem od pisania [... $]^{67}$.

\section{Z kolei w liście do Wierzyńskiego z 12 V 1948 pojawiły się jeszcze bardziej dra-} matyczne słowa:

Pozostaje mi samobójstwo albo powrót do Polski, jako ostatnia szansa włączenia się w jakiś, choćby ciężki i obcy, nurt życia. Bo tu płyną mi lata w nicości, a raczej w samounicestwieniu [...]. Na ogół ludzie unikają mnie jak trupa, być może, że z daleka czuć mój rozkład.

Rozterkę: czy pozostać w Ameryce, czy powrócić do Polski, potęgowało otrzymywanie zaproszeń z kraju. Do powrotu namawiali Wittlina m.in. Stanisław Ryszard Dobrowolski, Jarosław Iwaszkiewicz i Aleksander Wat, którzy chcieli pozyskać go dla „Nowin Literackich” i „Odrodzenia”68. Do wyjazdu z Ameryki skłaniał pisarza także pogarszający się stan zdrowia (dodatkowe problemy neurologiczne ${ }^{69}$ ) i związana $\mathrm{z}$ tym niepewność co do możliwości zarobkowania. Nie dziwi więc, że w liście do Hermanna Brocha z 14 IX 1948 Wittlin wspominał o planach wyjazdu do Polski

List ma niepełną datę: 12 VIII. Prawdopodobnie pochodzi z roku 1947 lub 1948. Informacje o śmierci swoich znajomych Wittlin czerpał z polskich gazet - polonijnych lub przesyłanych z Polski. Mogła to być prasa bieżąca, aktualna, albo numery archiwalne.

68 Zob. J. Wittlin, list do Cz. Miłosza, z 13 III 1947. Beinecke Library, New Haven. Archiwum Czesława Miłosza. Zob. też Listy Józefa Wittlina do Czesława Miłosza. Oprac. R. Z a ją c z k o w s k i. „Pamiętnik Literacki” 1917, z. 1, s. 171.

69 J. Wittlin wspominał o tym w liście do H. Brocha z 22 XII 1948 (Beinecke Library, New Haven. Archiwum Hermanna Brocha. Listy J. Wittlina do H. Brocha): „Kochany Bóg ma chyba wielki repertuar chorób. Ledwie pozbyłem się w sierpniu dolegliwości w dolnych rejonach ciała, od dwóch miesięcy słyszę bez przerwy tysiące cykad, tak jak latem na południu. Jest to tylko, jak twierdzą lekarze, zaburzenie nerwowe, ale bardzo nieprzyjemne, któremu towarzyszą bóle w różnych częściach głowy”. Konsekwencje tych schorzeń J. Wittlin opisywał 2 VI 1949 w liście do Janty-Połczyńskiego: „Ostatnio miałem ciężki znów okres pod względem zdrowia, dwa razy wywróciłem się wskutek trapiących mnie zawrotów głowy, raz nawet, w Palmową Niedzielę, porządnie się zraniłem tak, iż musiano mnie $z$ ulicy zawozić do najbliższego doktora, który mnie opatrzył i dał zastrzyk przeciwtężcowy”. 
w październiku 1948. Jednak pod koniec tego roku przyjął obywatelstwo amerykańskie $^{70}$, jakkolwiek miał poczucie rozdarcia. Wyraził to w liście do Wierzyńskiego z 1 XII 1948: „Obczyzna mi nie służy, a co do ojczyzny - zaczynam już tracić nadzieje”. Na początku 1949 r. Wittlin wiedział, że nie wróci do kraju, i 14 III pisał do Haupta:

Moja podróż do Polski jest już w sferze nierealnych rojeń. A jak Panu z pięknej i mądrej książki Janty (czytał Pan ją zapewne?) wiadomo, u nas w kraju obowiązuje tzw. realizm przedsocjalistyczny, od którego jestem daleki, mimo iż nie bardzo rozumiem, co to znaczy ${ }^{71}$.

Na decyzję Wittlina, żeby jednak zostać w Ameryce, wpłynęły różne czynniki. Najbardziej prawdopodobnym powodem wydaje się to, że na emigracji mógł on zachować wolność słowa, niezależność od władzy i politycznych nacisków. Nic więc dziwnego, że trzy lata później Wittlin namawiał Miłosza, aby on także zamieszkał na stałe w Ameryce, przypominając, że twórczość niejednego pisarza rozkwitła właśnie poza krajem ${ }^{72}$. Istniały wówczas również poważne obawy, że komunizm rozleje się na Europę ${ }^{73}$.

$Z$ roku na rok Wittlin czuł się coraz bardziej wyizolowany w miejscu swego osiedlenia. Pobyt w Nowym Jorku paraliżował jego zdrowie i siły twórcze. Lata wygnania spowodowały, że tracił kontakty ze światem. 16 IV 1968 r. pisał do Kestena:

J. Wittlin rozważał to już wcześniej, choć bez entuzjazmu, o czym pisał 16 V 1945 do M. Grydzewskiego (Listy do redaktorów „Wiadomości”, s. 36): „Albo przyjmę obywatelstwo amerykańskie i będę się tutaj na stare lata męczył wśród najbardziej obojętnego i okrutnego środowiska, w jakim kiedykolwiek żyłem, starając się o wniknięcie w to środowisko, albo będę musiał wracać. Białym emigrantem nie mam zamiaru zostać. Nie mogąc skutecznie przyczynić się do wolności naszego kraju, pragnę zachować moją własną, prywatną wolność, o co tutaj rzeczywiście nietrudno, chociaż nędzarz naprawdę nigdzie nie jest wolny. Moja żona od jesieni na próżno zabiega o pracę, była parę dni w fabryce trykotaży, pisała listy w jakimś biurze handlowym, ale za powoli na tutejsze tempo". H. Wittlin w cytowanym wywiadzie tak opisywała decyzję męża o pozostaniu w Ameryce: „H. W.: [...] punktem głównym, kiedy on się zdecydował, że nie wróci do Polski, do PRL - to było tłumaczenie Hiroshimy - jedyna książka, którą posłał. Przetłumaczył Hersey’a Hiroshimę i napisał do tego przedmowę. Ta przedmowa jest włączona do Orfeusza.

A. F.-Z.: A w którym roku to było?

H. W.: Gdzieś w 46-tym, 47-ym... I tam zdjęli tę przedmowę i dali jakiegoś kretyna, który napisał kretynizmy. Mój mąż się na wszystko zgadzał, ale nie na zmiany tekstu. No i oczywiście bez zmian tekstu było trudno pomyśleć, żeby można było coś w tym czasie wydać, prawda? [...] Wreszcie pojechał do Polski jeden z konsulów tutejszych, który też już nie żyje. Był naszym przyjacielem. I on powiedział: "Panie Józefie, to nie dla pana, pan tam nie wytrzyma pięciu minut. Tam jest takie napięcie nerwów".

Do powrotu usilnie namawiał pisarza J. Tuw im, m.in. w liście z 31 VII 1945 (w: B. Dor o s z, Lechoń i Tuwim - dzieje trudnej przyjaźni. Warszawa 2004, s. 149-151).

71 Wittlin wspomina wydaną w Paryżu w 1949 r. książkę A. Janty-Połc zyń skiego, będącą relacją z podróży autora do kraju: Wracam z Polski 1948: Warszawa, Wroctaw, Kraków, Poznań, Szczecin-życie, polityka, gospodarka, sztuka, ludzie i zagadnienia. Książka spotkała się z bardzo niechętnym, wręcz wrogim przyjęciem w polskich niepodległościowych środowiskach emigracyjnych na Zachodzie, co przełożyło się na dotkliwy, wieloletni bojkot towarzyski Janty.

72 J. Witt li n, list do Cz. Miłosza, z 16 VII 1951. Beinecke Library, New Haven. Archiwum Czesława Miłosza. Zob. też Listy Józefa Wittlina do Czesława Miłosza, s. 179-180.

73 Zob. J. M. Fralado, Communist Conception of "Europe” and the Beginning of the Cold War. W: Europe, Nationalism, Communism. Essays on Poland. Frankfurt am Main 2008, s. 111-115. 
Muszę przyznać: po 29 latach nieobecności czuję się obcy tamtemu światu i poza językiem i literaturą czuję się coraz mniej związany z Polską. Przez co nie chcę powiedzieć, że tutaj czuję się jak w domu. W 100\% stałem się eskapistą i właściwie nigdzie nie należę.

Osłabienie organizmu i łączące się z tym choroby towarzyszyły pisarzowi przez następne dziesięciolecia. Stan jego zdrowia często był rzeczywiście zły, a pomoc lekarska nie zawsze okazywała się skuteczna. Nie ma powodów, żeby nie brać poważnie informacji zawartych w liście do Grydzewskiego z 7 VI 1965:

Nie chcę Cię zanudzać swoimi dolegliwościami, ale mam ich sporo, ostatnio - przyplątały się kłopoty z oczami, którym grozi glaukoma. Trzeba ja na gwałt powstrzymywać. Odbija się to na mojej zdolności czytania ${ }^{74}$.

Nic dziwnego, że sprzeciw wobec tezy o hipochondrii pisarza zdecydowanie wyraziła Halina Wittlin w liście do Stefanii Kossowskiej z 7 II 1977, a więc niespełna rok po śmierci męża:

Po uzyskaniu przed dwoma miesiącami os ta te c zn e go wy nik u badań, okazało się, że był on ciężko chory od wielu, wielu lat, prawdopodobnie od czasu pierwszej wojny, kiedy ciężka infekcyjna choroba, fałszywie przez wojskowych lekarzy rozpoznana jako druga w życiu szkarlatyna, zniszczyła jego szpik kostny. Piszę to Pani po to tylko, żeby skończyć bajkę o hipochondrii ${ }^{75}$.

Opowieść o nieznanych faktach z życia Wittlina w Ameryce można ciagnnąć dalej. Jeśli kiedyś powstanie biografia pisarza, jej autor będzie musiał też sięgnąć do prawie zupełnie nie zbadanych 134 kieszonkowych notatników, obejmujących okres od lat dwudziestych do sześćdziesiątych XX wieku. Zawieraja one osobiste przemyślenia, komentarze do bieżących wydarzeń, notatki do planowanych utworów, zapisy z podróży etc. Stanowią też bardzo interesujące świadectwo ewolucji duchowej oraz intymny komentarz Wittlina do własnej twórczości i wydarzeń XX w. - zwłaszcza w Polsce i w Stanach Zjednoczonych. W notatnikach znajduje się także najbardziej szczery, choć krytyczny opis Ameryki, zdecydowanie odbiegający od tego, który wyłania się z nieopublikowanych tekstów autora Soli ziemi. W swych prywatnych zapiskach kreśli on obraz Stanów Zjednoczonych jako kraju zmaterializowanego i zlaicyzowanego, zdominowanego przez płytką rozrywkę, cechującego się brakiem wyższych uczuć. (Inna sprawa, w jakim stopniu opinie te były obiektywne, prawdziwe.) Amerykę często Wittlin przeciwstawiał Europie. Stąd w jednym z jego notesów znalazło się zaskakujące na pierwszy rzut oka wyznanie: „Lepiej być żebrakiem w Paryżu niż milionerem w New Yorku"76. Ten najgłębiej ukryty obraz świata, a zwłaszcza Ameryki i Europy, pozostawiony przez Wittlina (jego „nienapisany esej”) to jednak temat na osobną opowieść: o człowieku, który - jak zauważyła jego żona - „po prostu nie potrafił kłamać i to może mu utrudniało pisanie”77.

Ale mamy i drugą stronę medalu. Wittlinowy obraz Ameryki nie jest oczywiście jedyny. Poczet autorów polskich, którzy pisali o kraju Waszyngtona z perspektywy

Wittli in, Listy do redaktorów „Wiadomości”, s. 310.

H. Wittlin, list do S. Kossowskiej. W: jw., s. 501-502.

Notatniki J. Wittl in a. Muzeum Literatury im. A. Mickiewicza w Warszawie. T. 10, notatnik 121, k. 520, 1960 r., sygn. 1701.

77 Cyt. za: N. Tay lor - Te r le c ka, Orfeusz i Kostucha. Ostatnie chwile Józefa Wittlina. „Konteksty Kultury" 2015, z. 4, s. 500. 
emigrantów, okazuje się bardzo długi. Wystarczy wspomnieć choćby Czesława Miłosza, Aleksandra Jantę-Połczyńskiego, Kazimierza Wierzyńskiego, Marię Kuncewiczowa, Zygmunta Haupta, Jerzego Kosińskiego, Wojciecha Karpińskiego, Stanisława Barańczaka... Z gruntu odmienne sa obrazy, jakie zostawili Janta i Wierzyński. Ten pierwszy zasłyną z interesujących reportaży poświęconych Ameryce: Odkrycie Ameryki (1936), a krótko przed śmiercią wydał szkice Przyjemnie zapoznać (1972), traktujące o wielkich Polakach w Stanach Zjednoczonych, oraz tom pamiętników Nowe odkrycie Ameryki (1973). Drugi ogłosił książkę Moja prywatna Ameryka (1966). Wzmianka o tych publikacjach jest o tyle uzasadniona, że obejmują one relacje $z$ tego samego czasu i napisane zostały przez ludzi znających dobrze Amerykę, a przy tym będących nieprzeciętnymi twórcami i dobrymi przyjaciółmi Wittlina. Janta notuje swe myśli z pozycji reportera, chwytającego na gorąco obserwowaną rzeczywistość, pozostawia zapisy chwil i ludzi, omawia często sprawy interesujące zarówno dla Polaków, jak też dla Amerykanów, bawi i wzrusza jednocześnie. $Z$ kolei Wierzyński w swych szkicach, wygłaszanych pierwotnie na falach RWE, przygląda się temu krajowi jakby $z$ oddalenia, wspomina wybitne osoby i znane zwyczaje społeczeństwa amerykańskiego (co może jest ukłonem wobec sponsorów rozgłośni). Kładzie nacisk na to, co wielkie i typowe dla Ameryki; daje monumentalny obraz jej wyjątkowości i piękna.

To, co autor Soli ziemi napisał o Ameryce, należy traktować jako jego osobistą opinię, w dodatku opartą na niewielkiej znajomości kraju osiedlenia. Wittlin wypowiedział szereg gorzkich słów pod jego adresem. Niekiedy robił to otwarcie, ale najczęściej w ukryciu, pisząc do szuflady. Obwiniał wtedy Amerykanów o zerwanie z tradycją klasyczną, zmaterializowanie i spłycenie życia, zanik wrażliwości na sprawy ludzi i Boga. Wittlin należał do tych emigrantów, których Ameryka rozczarowała i którzy nie znaleźli w niej swego miejsca. Czy jego oceny nie są zbyt krytyczne? Czy nie pokazuja obrazu Ameryki jednostronnie? Czy są adekwatne w stosunku do bogatych, różnorodnych przejawów życia tego wielkiego kraju? Zapewne nie mogå być jedynym odzwierciedleniem rzeczywistości amerykańskiej, gdyż prawie zupełnie pomijaja jej pozytywne strony. Drażnią, składają się na wizję prowokacyjną, zmuszają do dyskusji o micie Ameryki.

Abstract

RYSZARD ZAJĄCZKOWSKI John Paul II Catholic University of Lublin

\section{JÓZEF WITTLIN - TRACING ESCAPE AND SALVATION}

The article refers to war and post-war life of Józef Wittlin and his family. It initially depicts his trials and tribulations from the moment of the poet's departure to the former Royaumont Abbey near Paris in June 1939 till his voyage from Lisbon to the USA in January 1941. From the moment Wittlin reached America he permanently lived in New York, struggling with numerous health and financial problems. In spite of that he continued his writing, and was even laureate of American awards for literature. In the year 1948 he finally decided to stay in America. His memories (continued till his death, though not always published) depict America as an emigrant-unfriendly country. Truly, however, Polish writers (e.g. Aleksander Janta-Połczyński, Kazimierz Wierzyński, Czesław Miłosz) left also a different images of this country, and Wittlin's voice should not be seen as the only reflection on American reality since it almost completely neglects its positive sides. All in all, Wittlin gives a provocative vision of the country and compels to a discussion on the American myth. 